https://doi.org/10.18485/iipe_60nam.2021.ch11

\title{
THE IMPACT OF POLICY OF NON-ALIGNMENT ON YUGOSLAVIA'S STATUS IN WESTERN EUROPEAN INTEGRATIONS
}

\author{
Duško LOPANDIĆ ${ }^{1}$ \\ Ratomir MILIKIĆ ${ }^{2}$
}

\begin{abstract}
The authors are discussing a Cold-War evolution of relations between post-war Yugoslavia and two Western European regional organisations, the Council of Europe and the European Economic Community. The two relationships appear to have been meaningful, yet of fluctuating intensity. What substantially shaped them was a strategic focus on non-alignment by the Yugoslav government and the country's president for life, Josip Broz. While relations with the Council of Europe unfolded largely in the political sphere, ties and contractual relationships between the Socialist Federal Republic of Yugoslavia and European communities were linked closely to the country's economic interests (trade, finances, etc.). Together with the internal system, it constituted a considerable limiting factor when, after the death of Tito, global changes across Europe prompted a debate on the prospects of Yugoslavia's potential membership of those organisations.
\end{abstract}

Key words: Non-Aligned Movement, Council of Europe, European Community, Tito, Cold War, European integrations.

\section{Introduction}

Yugoslavia's foreign policy after the Second World War went through several stages. After an intense yet short-lived rise in cooperation with the

\footnotetext{
${ }^{1}$ Professor and ambassador, Ministry of Foreign Affairs of the Republic of Serbia. E-mail:dulopand@yahoo.com.br

${ }^{2}$ Senior research associate, Institute for Contemporary History.

E-mail: milikicrasa@gmail.com
} 
Union of Soviet Socialist Republics (USSR) and the countries of the Eastern Bloc, there came the 1948 Cominform Resolution, a breaking point in the relationship that left Yugoslavia standing isolated by the socialist countries. Perhaps the best illustration of Belgrade's approach to the West in the early 1950s was the conclusion of the 1953 Balkan Pact with Greece and Turkey essentially an indirect link between Yugoslavia and the North Atlantic Treaty Organisation (NATO). This period, too, was fairly short. After the death of Stalin, from the mid-fifties onwards, Yugoslavia simultaneously normalized relations with the USSR and gradually built closer political ties with Asian and African states, which culminated in the establishment of the Non-Aligned Movement. After its first conference hosted by Belgrade in 1961, both under Tito and after his death, the country's foreign policy revolved around its leading position within the Non-Aligned Movement until the dissolution of Yugoslavia in the 1990s. The $9^{\text {th }}$ Summit of the NonAligned Movement held in Belgrade in 1989 was the proverbial swan song of Yugoslav foreign policy, sung on the eve of an ultimate crisis and the disintegration of the country. During the Cold War, with Europe divided by the Iron Curtain, Yugoslavia was a country outside the blocs that could lead an active foreign policy through the Non-Aligned Movement, and advocate changes in international conditions during the period of decolonisation and development of a New Economic Order. It does not mean though that Yugoslavia's foreign policy did not have a European dimension. As Leo Mates pointed out, "Yugoslavia's European policy has been inspired since the beginning of the post-war period by an active attitude and aspiration to contribute to the unification of Europe." (Mates, 1976, 168). In that sense, Yugoslavia's foreign policy achievements in a global context (within the Non-Aligned Movement) facilitated a more active and flexible Yugoslav policy in the early 1960s, as regards various forms of European regional cooperation and integration. Efforts were made to make sure that, in addition to active bilateral relations with almost all European states, Yugoslavia developed multilateral ties in Europe as well. "The intensification of relations with European countries coincided with the beginning of Yugoslavia's activities in developing relations with non-aligned countries ... In fact, the successes of the policy of connecting with less developed countries outside Europe enabled increased Yugoslav activity in Europe. That activity was objectively made possible by the development of relations on the continent." (Mates, 1976, 169). As early as 1955, Yugoslavia secured observer status in the OECE/OECD (an agreement with the Organisation for European Economic Cooperation - OECD was signed in 1961). The first contacts with the European Economic Community (EEC) were established in the early 1960s. Yugoslavia established diplomatic 
relations with the EEC (opened a diplomatic mission in Brussels) in 1968, having concluded a trade agreement with the European Free Trade Association (EFTA) countries in 1967. As pointed out by some historical studies, Yugoslavia's focus on agreements with Western European regional economic organisations (OECD, EEC, EFTA) was associated with the development of economic and trade relations with Western Europe on the one hand, while on the other the Yugoslav leadership was concerned that the emergence and expansion of regional economic integrations might produce considerable protectionist consequences threatening the position of Yugoslav exports. Accordingly, Yugoslavia was trying to conclude an agreement with the EEC since the organisation was established. At the same time, the SFRY entered into a special agreement on cooperation (1963) with the Eastern European Organisation for Mutual Economic Assistance (CMEA), thus attaining a special status in both Western and Eastern European regional organisations in the early 1960s. With a détente unravelling and preparations underway for the Helsinki Summit (the Conference on Security and Cooperation in Europe - CSCE) in the early 1970s, Yugoslavia became very active (in a group of neutral and non-aligned European countries) with a view to implementing successfully this initiative. Further below the authors will examine the development of ties between the SFRY and two Western European regional organisations - the Council of Europe (CoE) and the European Economic Community (EEC) - in a time span of over three decades. Whereas relations with the Council have always developed in a predominantly political context, the ties and contractual relationships with the European Communities centred on Yugoslav economic interests (trade, financial, etc.). In either case, though, the prospects of deepening the relations and even changing the potential status of Yugoslavia in these organisations were tied to its strategic orientation in the Movement. Together with the internal system, it constituted a considerable limiting factor after Tito's death; global changes across Europe prompted a debate on the prospects of Yugoslavia's potential membership of those organisations.

\section{Yugoslav Foreign Policy and the European Economic Community (1960-1991)}

Relations between the SFRY and the European Economic Community could be divided into several phases: 
A period of establishing and improving relations, with the conclusion of the first trade agreements between the SFRY and the EEC (1965-1980);

A period of intensification of cooperation, which began with the conclusion of a very important Cooperation Agreement (1980-1989);

The final phase: as the SFRY crisis deepened, an attempt was made to improve cooperation, as well as a fairly short-lived effort by the EEC to prevent the disintegration of Yugoslavia (1989-1991).

\section{The period of establishing, improving and institutionalizing}

\section{SFRY-EEC relations}

Relations between the SFRY and the European Economic Community can be viewed from different angles, involving interconnected factors such as political and diplomatic, economic and institutional (contractual). ${ }^{3}$ Although the EEC was founded to bring about economic integration (customs union), it always had both a political background and implicit yet important political goals (Dinan, 2010, 17; Šmale, 2003, 245). During the 1960s and 1970s, the industrialisation and urbanisation of Yugoslavia gained momentum. The process involved considerable Western technology imports, also creating a need for markets in Western Europe to be open to Yugoslav exports, especially in the sectors of agriculture and food production. Consequently, the creation of the customs union and the Community's pronounced agricultural protectionism directly affected Yugoslav economic interests. This process encouraged the pragmatic Yugoslav leadership to regulate trade relations with Brussels. A third of Yugoslavia's foreign trade partners were the EEC members, with the occasional spike in the ratio to around 40\% (1970). A trade deficit aside, total trade between the SFRY and the EEC grew rapidly over the two decades between 1958 and 1980, increasing 19 times. ${ }^{4}$ From a political angle, it is important to note that the USSR and the Eastern Bloc countries treated the EEC as an emanation of the Western Bloc's Cold-War policy. As a result, the socialist countries refused for a long time to accept the international legal

${ }^{3}$ The EEC had six members until 1973 when the number increased to nine, and after 1981 to 10. The EEC had 12 members in the early 1990s when Yugoslavia entered a fatal crisis.

${ }^{4}$ Yugoslavia's trade with the EEC increased from \$387 million in 1958 to $\$ 7.4$ billion in 1980. 
subjectivity of the Community (as a customs union). Not a single member of the Eastern Bloc (except for Romania) would sign an economic agreement with the EEC until the late 1980s. Yet the socialist and non-aligned Yugoslavia has conducted a very different policy in that respect. As early as 1968, Yugoslavia opened a diplomatic mission to the EEC at an ambassadorial level in Brussels. The rapid development of contractual relations to handle trade-related problems (especially in the field of agricultural and food products) that affected Yugoslav exports was marred by severed diplomatic ties between Belgrade and Bonn (the Holstein Doctrine). ${ }^{5}$ The problem was not resolved until 1968, when relations between the Federal Republic of Germany and the Socialist Federal Republic of Yugoslavia were re-established. It is equally important to note that EUSFRY relations were institutionalised (mission, agreement in 1970) during or after the Soviet intervention in Czechoslovakia in 1968. The year 1970 was a watershed moment in the EEC-SFRY relationship, as the two parties concluded their first trade agreement. It had a great impact at that time, primarily because of its implicit political significance. It was the first agreement that the EEC concluded with a socialist country. The agreement was non-preferential in nature, and the two parties agreed on a most favoured nation clause. A mixed commission for cooperation was formed as well. The following years saw further progress. In 1971, Yugoslavia was included in a scientific and technical cooperation initiative, the COST programme. In addition, the EEC extended to Yugoslavia a very important system of generalised customs preferences. Shortly after, in 1973, a somewhat broader trade agreement was signed between the two sides, which contained the so-called evolutionary clause, i.e., a possibility to expand contractual economic cooperation to other issues (in addition to customs and bilateral exchange regime). In 1976, a special agreement on trade in textile products was signed as well.

Development of relations in the context of a new Cooperation Agreement - between the policy of non-alignment and the need to strengthen cooperation further (1980-1989)

As economic relations between the two sides developed and the EEC grew stronger in the 1970s, with an emerging prospect of Greece's accession

\footnotetext{
${ }^{5}$ West Germany automatically severed diplomatic relations with the states that would establish diplomatic relations with the German Democratic Republic, abbreviated to GDR (East Germany).
} 
to the Community, a growing need presented itself to solidify contractual relations between the EEC and Yugoslavia with a view to regulating the relationship on a broader and longer-lasting basis. This time a much more ambitious agreement was in the pipeline, taking into account the expansion of EEC preferential trade agreements for developing countries, especially within so-called association agreements for the Mediterranean countries, i.e., Algeria or Morocco (Samardzic, 2009). ${ }^{6}$ This issue, however, opened a political debate in Yugoslavia about the possibility of a non-aligned country being associated with the European Community. The question was whether the EEC association process was in contradiction with genuine nonalignment. In this context, the 1976 Joint Declaration signed in Belgrade by high-ranking representatives of the EEC and Yugoslavia (the drafting of which involved consultations with SFRY President J. B. Tito) was a very important step. The "non-aligned position" of Yugoslavia was noted in the document (and in the Final Act of the Conference on Security and Cooperation in Europe signed in Helsinki, also known as the Helsinki Final Act) which was a kind of political confirmation of the Yugoslav status in relation to Western integration, i.e., the political limits of rapprochement between Yugoslavia and the Community. The Declaration also provided a political framework for the conclusion of a very ambitious and comprehensive Cooperation Agreement between the EEC and Yugoslavia, signed in 1980, shortly after Tito's death (Lopandić, 1985). ${ }^{7}$ In the eyes of the Community, the Agreement belonged to a group of so-called Mediterranean association agreements. Yet the term "association" was not mentioned in either the title or the body of the document, appreciating Yugoslavia's sensitivity. From a political point of view, the Preamble that defined Yugoslavia as a "non-aligned, European, Mediterranean state and a member of the Group of 77" was particularly important, as it was those four terms that delineated a geopolitical framework of cooperation between the two parties. In the field of trade privileges, Yugoslavia was granted a so-called preferential position. Significant financial support was provided under

\footnotetext{
${ }^{6}$ According to then Article 238 of the EEC Treaty, which provided for the possibility of an EEC accession agreement. The same article was used later as a legal basis to conclude association agreements with Eastern European countries, as well as stabilisation and association agreements with the Western Balkans.

7 This was no coincidence. Negotiations, which had been blocked due to some commercial issues, were abruptly unlocked by an EEC decision that coincided with the news of the Yugoslav president's illness.
} 
additional protocols to the Agreement as well. The document also covered trade, economic, technical and social cooperation. It was an indefinite duration contract, unlike previous bilateral arrangements between the two parties. A European Commission delegation was opened in Belgrade in 1980 as yet another confirmation of thriving bilateral ties. Additional protocols to uphold the development of cooperation were signed in the 1980s as the volume of favourable loans by the European Investment Bank to boost infrastructure in Yugoslavia grew constantly. Special mention should be made of a new EEC financial protocol signed in 1985, providing for favourable EEC loans worth 550 million ecus (today's Euros), which was the most extensive financial protocol that the EEC had ever concluded with a Mediterranean country (EEC-Yugoslavia cooperation council, Memo 90/64).

The closing era - the SFRY's existential crisis and an attempt to improve cooperation in the course of it, and a fairly short-lived effort by the EEC to prevent the disintegration of Yugoslavia (1989-1991)

At the onset of a substantial geopolitical shift in Europe, prompted by cooperation within the CSCE, and even more, by two new policies in the USSR, "glasnost" and "perestroika," new ways of more dynamic cooperation and integration in Europe were launched. The fall of the Berlin Wall in 1989 heralded the process of unification of Germany (1990), encouraging a complete recomposition of the European political architecture and the birth of a new Europe. The EEC grew in importance after a fresh step had been made in the process of economic integration - a single market programme referred to as Europe 1992. The appeal of the Community was made quite visible as new applications for membership arrived in the late 1980s (by EFTA members - Sweden, Norway, Austria and Finland). ${ }^{8}$ It was against such a backdrop that tensions grew and a political crisis deepened in Yugoslavia, sparking debates about the future of Yugoslavia's relationship with the EEC, more precisely, about "turning away from the Third World into Europe". 9 "The deepening crisis and new disagreements

${ }^{8}$ Norway signed an EEC membership agreement but decided against joining the Community in a national referendum.

${ }^{9}$ Among other things, it is important to note the 8th session of the Central Committee of the League of Communists of Serbia in 1987, at which Slobodan Milošević defeated Ivan Stambolić's political line. In 1989, a grandiose event was held by S. Milošević in Gazimestan, Kosovo and Metohija. Early in 1990, the 
have opened up the problems of relations with the EEC to the end, posing them not only as an economic but also as a distinct political alternative." (Vukadinović, 1990, pp. 83-106). In principle, Yugoslavia's further policy towards the Community crystallized into three options (Vukadinović, 1990):

- The continuation of the policy of non-alignment with no major changes as to cooperation with the EEC. Such views, among other things, were advocated by more conservative Yugoslav officials, ${ }^{10}$

- The idea of an "urgent entry" into the EEC, involving political and economic reforms the political decision would entail;"11

- Finally, there was a more limited idea suggesting so-called "functional cooperation" that would not be incompatible with the Yugoslav nonaligned position. The preferred type of cooperation would develop along the lines of Yugoslavia's inclusion in the EFTA organisation, paving the way to ties within the group of neutral and non-aligned European countries while also avoiding political marginalisation in a new Europe. (Vukadinović, 1990).

The then Yugoslav government's official policy mirrored the orientation that had taken into account global shifts and changes at home. Late in 1989, at the Ministerial Cooperation Council, a Yugoslav delegation led by the Federal Secretary for Foreign Affairs B. Lončar proposed that a new type of association agreement be signed with the EEC. The European Commission's idea that a new contractual framework be prepared for the SFRY to include accession, stronger financial ties and Yugoslavia's involvement in the Phare programme of support to Central and Eastern European countries was overshadowed by an exacerbated situation on the ground, as conflicts and wars spiralled in Slovenia, Croatia and Bosnia and Herzegovina. In mid-

League held its last conference which was interrupted. It was at this last party Congress that the party organisations of Yugoslavia's six republics split, heralding the disintegration of the country in the second half of 1991 and early in 1992. Finally, Slovenia held a referendum on independence in the late 1990s.

${ }^{10}$ Like Branko Mikulić, the prime minister of the federal government from 1986 to 1989.

${ }^{11}$ According to Vukadinović (1990), this was advocated by some Slovenian and Croatian economists, who argued that admission to the EEC should be requested immediately. A Croatian economist, Marijan Korošić, was the most radical, and the Slovenian Social Democrats included this request in their political platform. It was later accepted by all newly formed parties in Slovenia and Croatia. 
1991, the EEC members tried and failed to prevent or at least slow down the disintegration of Yugoslavia through political statements and actions on the ground by the Ministerial Troika mission the Community had sent to Yugoslavia. The so-called Carrington's Conference on Yugoslavia in September 1991, followed by the suspension and cancellation of the EECYugoslavia Cooperation Agreement and Protocols two months later in November 1991, effectively ended the bilateral relationship. A new chapter was opened of EEC/EU involvement in the Yugoslav conflicts, including sanctions, diplomatic mediation, peacekeeping missions, conferences on the former Yugoslavia, etc.

\section{Relations between Yugoslavia and the Council of Europe through the prism of cooperation with non-aligned states (1954-1991)}

In the wake of the Cominform Resolution and the break with the Soviet Union and the Eastern Bloc in the summer of 1948, a sudden convergence occurred between Yugoslavia and the West. Communist Yugoslavia was under constant pressure from yesterday's allies, the Eastern Bloc countries. Sabre-rattling, border disputes and skirmishes, often deadly, made Tito and his closest aides (most of whom remained loyal to him) to turn to the United States and the West. They first asked for food, then for arms. First consignments of U.S. large-scale aid were dispatched to the country, and it was a strategic priority for the newly-formed NATO (1949) to arm those Yugoslav units that defended two key geographic areas in Yugoslavia, the Ljubljana Gap and the Vardar Valley (EC Decision, 1991). The political relationship grew closer, too, bringing forth fresh political initiatives. Initially, it was regional cooperation governed by the Treaty of Ankara, signed in 1953, expanded shortly after the Bled agreement (1954). The two documents created regional fundamentals for the neighbouring states that until yesterday battled each other on political and military grounds - Yugoslavia, the Kingdom of Greece and Turkey. Aside from a long and complicated history, exacerbated by wars, unresolved border disputes and millions of refugees on both sides, the last two had one more thing in common - NATO membership. It is noteworthy that the Balkan Alliance was actually a military regional organisation, as was the subsequent Balkan Pact, designed as a well-branched structure that should have been permanently headquartered in Belgrade. The North Atlantic Alliance was behind the organisation, militarily and politically (Milikić, 2008, pp. 622-624). A duty for member states to assist each other if attacked by a third party was an elegant way to place Yugoslavia under the NATO umbrella, without developing with the Alliance any deeper 
institutional cooperation or any cooperation for that matter. What the new regional ties gave Yugoslavia was the country's sudden opening towards Europe, which Tito's travel to Great Britain in 1953 and Paris in 1956 testified to (Milikić, 2014, p. 235). As part of the regional cooperation, Tito travelled to Athens, Ankara and Corfu as well (The Archives of the Ministry of Foreign Affairs, 1954). The Greek MPs acting as negotiators in building the Balkan Consultative Assembly suggested to the Yugoslav party that it should consider as a model the Consultative Assembly of the Council of Europe (later the Parliamentary Assembly), an organisation Western European states had set up in Strasbourg in 1949 (Milikić, 2014, pp.137-140). ${ }^{12}$ Since its inception, the focus of the Council has been on the protection of human rights, democratic values and the rule of law (Milikić, 2013, pp. 399-410). ${ }^{13}$ Owing to the Greek MPs, Yugoslavia developed substantial cooperation with the organisation, but it was short-lived. A decision by the Council of Europe in 1955 to reject Yugoslavia's request for the recognition of its observer status marred the ties between Belgrade and the Council, coinciding with some peculiar shifts in the country's foreign policy. The same year Nikita Khrushchev stunned Western diplomats with a visit to Belgrade, apologising for his predecessor Joseph Stalin's policy. In a skilful move, Tito turned his back on the West while remaining fairly independent from the Eastern Bloc and the USSR (Bogetić, 2006, pp. 29-30). From then on, Europe, the Council of Europe and regional cooperation were rare themes to come across in diplomatic dispatches. Not long before, with clear signals emerging that Yugoslavia should formalise closer ties with the Council of Europe, the situation in decolonised Asia and

12 The initial vision of the Council of Europe was that of an umbrella political organisation for European cooperation of the "free world." It was based on the unity of the Western Allies led by Winston Churchill. Even at the earliest stages, a clash of views emerged between European federalists and sovereigntists, with repercussions on the development of the organisation in the future. When in the early 1950s France sabotaged a plan for a military component of European cooperation, the European integration took a different, economic turn towards European communities, lending the Council a strictly supervisory and advisory role it still has today.

${ }^{13}$ Shortly before the establishment of the Council of Europe, the Hague Congress took place in 1948, attended by representatives of Western European states and some émigré organisations developed in the states behind the Iron Curtain. The Congress laid the cornerstone of not only the organisation but the subsequent European integrations, too. Milan Gavrilović, Živko Topalović and Juraj Krnjević were among the attendants. 
Africa had become a recurrent theme in diplomatic correspondence. In the same context, the conferences in Colombo and Bandung, held in 1954 and 1955, respectively, were monitored very closely (Bondžić, Selinić, 2008, pp. 7184). The exponent of a pro-European policy was Foreign Minister Koča Popović, while the Yugoslav speaker, Moša Pijade, was the architect of a proactive policy towards new states, first within the United Nations and then on a bilateral level. Shortly after, Tito's visits to India and Burma followed in 1954 and 1955, and a new chapter in Yugoslavia's foreign policy was opened, leaving the Western European pages, if not exactly closed, then certainly neglected. To facilitate an overview of Yugoslavia's relations with the NonAligned Movement on the one hand and the Council of Europe on the other, it is important to say that those relations moved along completely separated tracks, at varying levels of intensity, but that on occasion the two lines would come closer to each other. After the cold spell in the relationship with the Council in 1955 and 1956, Yugoslavia remained very passive until the end of the 1960s when, at the initiative of the Council, relations thawed again. Belgrade changed its foreign policy course, with a clear shift in the policy towards European states too. It was then that Yugoslavia articulated its interest in the Third World and became one of the leading members of the NonAligned Movement. Late in the 1960s, however, Secretary-General of the Council of Europe Peter Smithers (Great Britain) arrived in Belgrade, bringing new warmth to the Belgrade-CoE relationship (Milikić, 2017, p. 88, 95-106). The sixties saw a sudden rise in power of the Non-Aligned Movement. It consistently supported national liberation movements in Africa, fighting for the restructuring of the global economy as well. At a summit conference in Algeria in 1973, the Movement laid down a series of measures to be taken to establish a new international economic order, requesting the Group of 77 to carry out the initiative within the UN General Assembly. Group 77 was formed as a coalition of Third World countries, and it was under the auspices of the group that the Joint Declaration of Developing Countries was passed in 1963. The declaration contained a call for reforms leading to a more balanced exchange in North-South trade (Kegley and Wittkopf, 1997, p. 326).

In the early 1970s détente was negotiated to relax strained international relations, the Helsinki Final Act was signed and the Conference on Security and Cooperation in Europe (CSCE), later the Organisation for Security and Cooperation in Europe (OSCE), was established. Yugoslavia has been very active in this organisation since its inauguration. Relations with the Council of Europe improved considerably as well, and a string of high-level visits and Yugoslavia's accession to three $\mathrm{CoE}$ conventions further deepened the relationship. The latter made Yugoslavia the first state behind the Iron 
Curtain that entered a contractual relationship with the oldest panEuropean organisation.

It came as a surprise to many international stakeholders to see the SFRY Federal Secretary of Foreign Affairs, Miloš Minić, speaking before the Parliamentary Assembly of the Council of Europe in January 1975 during an equally unexpected visit to the Council. While presenting the priorities of his country's foreign policy, Minić placed special emphasis on the policy of nonalignment, but also shared Yugoslavia's openness to restoring the relationship with the Council. Using the parts of the session that were open to the public, as well as those behind closed doors, Minić discussed with members of the Parliamentary Assembly opportunities for non-aligned and other states to play a more active role in resolving global issues together with great powers, suggesting a round table conference where all European and many nonaligned states would be represented, making the idea of equal participation a reality (Milikić, 2017, pp.158-160; 188-189; 202-203). The Federal Executive Council adopted under item 20 of the agenda for a session of the Council on 13 March 1975 a brief on the visit to the Council of Europe by Miloš Minić, a vice-president of the Federal Executive Council and the federal foreign secretary. The Council found that the Federal Secretariat of Foreign Affairs should continue to monitor development trends within the Council of Europe, especially potential initiatives for further contacts and exchange of opinions with Eastern European and non-aligned states on European and global cooperation, with a view to shaping a national stance in each particular case. Proceeding from the modes of cooperation that had been already established by the Council of Europe, opportunities should be explored to expand it so as to include those areas and specific issues where mutual interests existed (italicized text, R.M.) (The Archives of the Ministry of Foreign Affairs, 1975).

After Tito's death in 1980, enhanced cooperation was noted along both routes of Yugoslavia's foreign policy - within the Non-Aligned Movement and in European politics alike, especially with the Council of Europe and the European Community. In the eyes of the Council, Yugoslavia had been a bridge to the Movement since the early 1980s, as well as a link to certain non-aligned states. One of the many examples to illustrate the point was a visit to Strasbourg in 1984 by the SFRY's high-ranking parliamentary delegation led by the speaker, Vojo Srzentić. ${ }^{14}$ The plan was for the high-

${ }^{14}$ Before the speakership, Srzentić was the secretary of the Bar Municipality, the president of the Central Committee of League of Communists of Montenegro and a member of the SFRY parliament. 
ranking parliamentary delegation to travel at the invitation of the European parliament, but it was only at the insistence of the Yugoslav ConsulateGeneral in Strasbourg that talks at the Council of Europe were added to the itinerary (PACE Archives, 1983). ${ }^{15}$ The Yugoslav delegation was expected to meet with the president of the Parliamentary Assembly of the Council of Europe and its officials, as well as the Secretary-General of the Council of Europe, which was the highest level the Yugoslav parliamentarians could have been welcomed at. The best illustration of how eager the consulategeneral in Strasbourg was to promote the visit was a request for a joint communiqué after the talks and an announcement that a correspondent of the Tanjug state agency would be covering the meeting, aside from the Yugoslav delegation's agenda at the European parliament. It was noted during the talks about the visit between the Yugoslav consul-general in Strasbourg and Secretary-General of the CoE Parliamentary Assembly John Priestman that it was a general impression the visit would matter very much to the Yugoslav parliamentarians, and that any incentive for cooperation from the Council would be more than welcome. The Yugoslav diplomat suggested that it might be good to suggest to the president of the Assembly, Karl Ahrens, to support Yugoslavia's foreign policy ties with the NonAligned Movement. ${ }^{16}$ He underlined that the Yugoslav delegation would be more than pleased if it could return to Belgrade with a message that the Council of Europe had praised Yugoslavia's efforts over the past 30 years to reduce East-West tensions, as well as its active neutrality policy and leading role in the Non-Aligned Movement - more generally, the role of a mediator between Europe and the Third World (PACE Archives, 1983). And that is what happened. New meetings in the future, as well as the role of Yugoslav MPs and other officials in the work of the Assembly until the end of the 1980s, often served as a sounding board for support to the Non-Aligned Movement and clarification of Yugoslavia's foreign policy. When a Council of Europe delegation visited Belgrade in 1988 as part of preparations to tighten ties with Yugoslavia, it was welcomed by the country's top-ranking officials. The president of the SFRY Presidency, Lazar Mojsov, briefed his guests from Strasbourg not only on the foreign policy course tied to the Movement, but also on a considerable conscious effort by the state to conduct an active Balkan policy to promote

${ }^{15}$ The Parliament of the European Community, today's European Union, headquartered in Strasbourg and Brussels.

${ }^{16}$ German Social Democrat, member of the Parliamentary Assembly of the Council of Europe (PACE) from 1970 to 1991, the president of the Assembly from 1983 to 1986. 
peace and tolerance and develop closer ties within the European policy, if not pervasively, than in the spheres that at least one of the six Balkan states did not find controversial ((PACE Archives, 1988). It gained momentum within and shortly after a summit of the Non-Aligned Movement in Belgrade in 1989, as well as after Yugoslavia was granted observer status at the Parliamentary Assembly the same year. The general situation changed shortly after that. East and West Germany reunited, the Iron Curtain came down and Yugoslavia lost an aura of exceptionality; instead of accepting its request for membership, the Council of Europe turned into a stage where Slovenia first, and then Croatia, pleaded for independence. Other former Yugoslav republics soon followed the suit, and the Council would vigorously condemn the newly-formed Federal Republic of Yugoslavia until a democratic change in the country in 2000.

\section{Conclusions}

Yugoslavia's foreign policy after the Second World War went through several stages. After a short-lived rise in cooperation with the USSR and the states of the Eastern Bloc, the 1948 Cominform Resolution severed the relationship and left Yugoslavia isolated. Tito was steering Yugoslavia to the West to avoid hunger in the country, but also to compensate for military dispatches from the East, which he needed desperately to protect it against a potential attack by the Soviet Union and its allies. The next step was to create a new foreign-policy strategy targeted at pan-European organisations that existed on the other side of the Iron Curtain, where a democratic world was. Initially, it was cooperation with two neighbours, Greece and Turkey, under the Balkan Pact, after which contacts were made with the Council of Europe using the regional initiative. Relations with the European Community, too, were established in the aftermath of it. Even though relations between the USSR and Yugoslavia were thawing, the proEuropean foreign-policy tier was not fading away but instead progressed at a varying pace. From the mid-1950s on, in addition to the two existing foreign-policy tracks - one leading to the USSR and the Eastern Bloc and the other to the Western European states and their organisations Yugoslavia developed one more policy - the policy of non-alignment. It appears the last one grew ever stronger in the subsequent years; so much that at a point it played a lead role. The culmination of the political course was the Non-Aligned Movement, whose first conference was hosted by Belgrade in 1961 when Yugoslavia revealed itself as the leader or at least one of the most prominent leaders of the new group. From then on, under 
Tito and after his death, i.e., until the end of the last decade of the $20^{\text {th }}$ century and the dissolution of Yugoslavia, the country's foreign policy was based on her leading role in the Non-Aligned Movement. The Movement's summit hosted by Belgrade in 1989 was the swan song of Yugoslavia's foreign policy, sung shortly before a deep crisis engulfed the country, which disintegrated in a completely different international context.

\section{References}

Bogetić, D. (2006). Nova strategija spoljne politike Jugoslavije 1956-1961, Beograd, Institut za svaremenu istoriju

Bogetić, D. (2000). Jugoslavija i Zapad, Beograd, Službeni list

Bondžić,D. Selinić,S, (2008). Pogled iz Beograda na Bandušku konferenciju 1955 Istorija 20. veka, (p.71-84), Beograd.

Charles W. Jr. Kegley, Eugine R. Wittkopf (1997), World Politics: Trend and Transformation,New York, St. Martin Press.

Dimić, Lj. (2014). Jugoslavija i hladni rat, Beograd, Arhipelag.

Dinan,D. (2010). Menjanje Evrope - Istorija Evropske unije, Beograd, Službeni glasnik.

EEC-Yugoslavia cooperation council, Memo 90/64, retrieved from https://ec.europa.eu/commission/presscorner/detail/en/MEMO_90_64. 12.4.2021.

EC Decision. (1991). Council Decision of denouncing the Cooperation Agreement between the European Economic Community and the Socialist Federal Republic of Yugoslavia", Official Journal of the European Communities, No L 325/23.

Lopandic, D. (1994). The European Community and the Yugoslav crisis (1989-1992), Some issues of International Law, In: Jugoslovenska revija za medjunarodno pravo, XLI (3), pp. 311-350.

Lopandić, D. (1985). La Communaute economique euopeenne, Paris, Yougforanc. Mates, L. (1976). Međunarodni odnosi socijalističke Jugoslavije, Beograd, Nolit.

Milikić, R. (2017). Između Evrope i nesvrstanosti - Jugoslavija i Savet Evrope 1960-1980, Beograd, Institut za savremenu istoriju, Akademska misao.

Milikić, R. (2014). Zaboravljena evropska epizoda: Jugoslavija i Savet Evrope 19491958, Beograd, Institut za savremenu istoriju. 
Milikić, R. (2013). Serb émigrés of democratic european orientation, marginalized and forgotten, unrecognized by allies, shunned by descendants (Participation of Milan Gavrilović and Živko Topalović at the Hague Congress), in: National and European Identity in the Process of European Integration, pp.399-410, Belgrade, IMPP- Hanns Seidel Stiftung.

The Archives of the Ministry of Foreign Affairs. (1954). Political Records. File No. 27. Ambassy Report on Tito visit, confidential 45880, May 12.

The Archives of the Ministry of Foreign Affairs. (1975).. Political Records. File No.186. Decision by the Federal Executive Council, strictly confidential 414059, March 20.

Milikić, R. (2008) Nekolika pitanja jugoslovensko-turske saradnje 1952-1955, in: Spoljna politika Jugoslavije 1950-1961, Beograd, INIS, pp. 617-627.

PACE Archives. (1983). Yugoslavia - Historic Relations 1969-1989. X$\mathrm{KS} / \mathrm{mts}$, Le 15 decembre.

PACE Archives. (1983). Yugoslavia - Historic Relations 1969-1989. Visit to Strasbourg of the President of the Yugoslav Assembly (Skupština). Confidential, December 28.

PACE Archives. (1988). Yugoslavia - Historic Relations 1969-1989, AS/Bur (40)5, June 1.

Samardzic, S. (2009). Srbija u procesu pridruživanja Evropskoj uniji, Beograd, Službeni glasnik.

Šmale, V, (2003). Istorija evropske ideje, Beograd, Clio.

Vukadinović, R, (1990). European Challenges and Yugoslav Options, Croatian Political Science Review, Vol. XXVII, (1). pp. 83-106. 